\title{
Assessment of Tamil Nadu Agricultural University (TNAU) Mobile Apps among Mobile User Group in Tiruvallur District
}

\author{
R. Rajasekaran ${ }^{1}$, V. Jothika ${ }^{1^{*}}$ and R. Panneerselvam ${ }^{2}$ \\ ${ }^{1}$ Department of Social Sciences, Agricultural College and Research Institute, \\ Thoothukudi, Tamil Nadu, India \\ ${ }^{2}$ Farm Manager (Krishi Vinyan Kendra, Tirur, Tiruvallur, India \\ *Corresponding author
}

\section{A B S T R A C T}

Currently lot of Information and Communication Technology (ICT) tools are available for Transfer of Technology (TOT) this ICT tools are gradually replacing the traditional method of TOT, and personnel contacts methods. It act as an expert in diagnosing,

Keywords

Farmers, ICT, Information, Mobile app analyzing and problem solving in all areas (Agriculture, Medicine, Animal husbandry, etc.). In order to popularize ICT tools among farmers the Krishi Vinyan Kendra (KVK) located in Tirur village of Tiruvallur district taken a novel initiative. Three type of treatments among paddy growing farmers such as Farmers own experience, Farmers using existing extension methods for getting information on paddy (Extension officers and dealers) and Farmers using TNAU mobile apps for getting information on paddy were taken for assessment purpose. TNAU Mobile app was uploaded to 10 farmers. Demonstration on the use of Mobile apps was given to the beneficiaries. In case of mobile app the knowledge gained on new technologies is high and in case of their own experience it is nil. Adoption of new technologies is about $70 \%$ in case of mobile app utilization and $40 \%$ and $30 \%$ in case of conventional extensional services and farmers own experience respectively.

\section{Introduction}

Currently lot of Information and Communication Technology (ICT) tools are available for Transfer of Technology (TOT) this ICT tools are gradually replacing the traditional method of TOT, and personnel contacts methods. It acts as an expert in diagnosing, analyzing and problem solving in all areas (Agriculture, Medicine, Animal husbandry, etc.). But these technological tools are generated and practiced only in research system and public extension system. An expert system (ES) is a computer programme that is designed to emulate the logic and reasoning processes that an expert would use to solve a problem in his/her field of expertise, using artificial intelligence technology (Waterman 2004). The expert system purpose is not to replace the human expert yet to build their insight knowledge, experience and permit expert system to work 
better. (Tripathi 2011). ICT can be used to provide farmers with reliable information and services, thereby promoting a more remunerative agriculture development (Raghuprasad et al., 2012). Dhaka and Chayal (2010) stated from their study that larger proportion of the farmers utilized ICT for assessing price of the farm produce followed farmers getting information about crop production practices plant protection measures. Huge efforts were taken by the government to bring this technological tools to farmer's usage but lack of awareness and source of technology on latest innovative technologies on crop production is noticed among the farming community. In order to popularize ICT tools among farmers the Krishi Vinyan Kendra (KVK) located in Titur village of Tiruvallur district taken a novel initiative. Among the large number of available ICT tools the TNAU mobile apps (Expert system) is one of the best visual diagnostic and problem solving tool. Out of the six TNAU mobile apps (5 crop oriented and 1 Animal husbandry oriented) the paddy expert system is popularized among the farmers of Tiruvallur district. TNAU Paddy expert system is a mobile app for paddy that covers cultivation practices, nursery management, irrigation, crop nutrition, pest and disease management, harvest and postharvest technologies, schemes and marketing information and also it provide advisories to the farmers. This paddy expert system was developed by mobile seva and released on January 24, 2017.

\section{Materials and Methods}

\section{Selection of study area}

The basic details of Tiruvallur district based on the analysis made by the KVK during 2016-17 is summarised below:

(i) Major farming systems/enterprises prevailed in Tiruvallur District is given in following table.

\begin{tabular}{|c|c|}
\hline S. No & Farming system/enterprise \\
\hline 1. & $\begin{array}{c}\text { Irrigated } \\
\text { Rice-Rice-Rice } \\
\text { Rice-Rice-Groundnut } \\
\text { Pulses-Rice-Groundnut } \\
\text { Sugarcane-Sugarcane (Ratoon) }\end{array}$ \\
\hline 2. & $\begin{array}{c}\text { Rain fed } \\
\text { Rice-Groundnut-Millets/Pulses } \\
\end{array}$ \\
\hline
\end{tabular}

(ii) Description of Agro-climatic Zone \& major agro ecological situations (based on soil and topography)

\begin{tabular}{|c|c|c|}
\hline S. No & Agro-climatic Zone & Characteristics \\
\hline 1. & North Eastern Zone & $\begin{array}{l}\text { The district lies between } 12^{\circ} 10^{\prime} \text { and } 13^{\circ} 15^{\prime} \text { Northern latitudes and } 79^{\circ} 15^{\prime} \text { and } 80^{\circ} \\
20^{\prime} \text { Eastern longitudes. The average annual precipitation is } 1104.4 \mathrm{~mm} \text { with } 52 \text { per } \\
\text { cent benefit from North-East monsoon and } 41 \text { per cent from South-West monsoon } \\
\text { and the remaining } 7 \text { per cent from summer showers and winter rains respectively. } \\
\text { The mean maximum and minimum temperatures are } 37.9^{\circ} \mathrm{C} \text { and } \\
18.5^{\circ} \mathrm{C} \text { respectively. The area has semi-arid tropical climate. The hot climate } \\
\text { prevails during the month of March-April and the slightly cold climate from } \\
\text { December to February, the rest of years belong to humid climate. Tanks are the } \\
\text { most important source of irrigation in this zone closely followed by wells. . Due to }\end{array}$ \\
\hline
\end{tabular}




\begin{tabular}{|c|c|c|}
\hline & $\begin{array}{c}\text { tank and well irrigation, wetland and garden land cropping systems are in vogue } \\
\text { though major area is under dry land agriculture. The underground water potential } \\
\text { in this region is assessed to be good and this zone stands foremost in lift irrigation } \\
\text { from wells with large number of agricultural pump-sets. }\end{array}$ \\
\hline $\mathbf{2}$ & Hill Ecosystem & $\begin{array}{r}\text { Shallow to moderately deep (with rock phases) red soils of eastern ghats, loamy to } \\
\text { clayey with gravels, hot moist semi arid to dry semi arid transition (rainfall (750- } \\
\mathbf{1 0 0 0} \mathbf{m m} \text { ) with LGP 150-180+ days. }\end{array}$ \\
\hline $\mathbf{3}$ & Plain Ecosystem & $\begin{array}{r}\text { Moderately deep to deep, gravelly loam and gravelly clay red and lateritic soils of } \\
\text { plains, moist semi arid ecosystem (rainfall 1000-1500 mm with LGP 180-210 days) }\end{array}$ \\
\hline $\mathbf{4}$ & Coastal Ecosystem & $\begin{array}{c}\text { Deep to moderately deep, sandy soils of narrow coastal plain and gravelly clay and } \\
\text { gravelly loam soils of inland plain, hot moist semi arid to dry subhumid transitional } \\
\text { ecosystem (rainfall 1000-1500 mm) with LGP 210+ days. }\end{array}$ \\
\hline
\end{tabular}

\section{iii) Soil types}

\begin{tabular}{|c|c|c|c|c|}
\hline S. No & Soil type & Characteristics & $\begin{array}{c}\text { Area in } \\
\text { ha }\end{array}$ \\
\hline $\mathbf{1}$ & Coastal Sandy & $\begin{array}{c}\text { Deep to very deep solum, colour varies between dark yellowish brown to dark } \\
\text { brown. Sandy textured, single grained; excessively drained soils. pH varies } \\
\text { between 7.3 to 7.8. }\end{array}$ & $\mathbf{8 , 3 4 6}$ \\
\hline $\mathbf{2}$ & Coastal Alluvium & $\begin{array}{c}\text { Deep, light brownish gray to dark brownish gray coloured; sandy loam to } \\
\text { sandy clay loam textured; pH varies from 8.0 to 8.3 }\end{array}$ & $\mathbf{8 , 7 0 2}$ \\
\hline $\mathbf{3}$ & River Alluvium & $\begin{array}{c}\text { Deep solum, grayish brown to yellowish brown; sand to sandy loam textured; } \\
\text { pH varies from 6.1 to 6.3 Deep solum, yellowish brown to dark yellowish } \\
\text { brown; sandy clay to clay textured; pH varies from 7.9 to 8.3 }\end{array}$ & $\mathbf{1 5 8 2 0}$ \\
\hline $\mathbf{4}$ & Red soil & $\begin{array}{c}\text { Moderately deep, colour varies between dark brown to dark reddish brown; } \\
\text { loamy sand to sandy clay loam textured; pH varies from 6.6 to 7.3 }\end{array}$ & $\mathbf{1 0 6 7 9 9}$ \\
\hline $\mathbf{5}$ & Lateritic soil & $\begin{array}{c}\text { Moderately deep, red coloured; sandy clay loam to clay textured; pH varies } \\
\text { from 5.1 to 6.0 }\end{array}$ & $\mathbf{1 5 0 4 8}$ \\
\hline $\mathbf{6}$ & $\begin{array}{c}\text { Moderately shallow, yellowish red coloured; sandy clay loam to sandy clay } \\
\text { textured; pH varies from 5.5 to 5.7 }\end{array}$ & $\mathbf{8 , 6 4 9}$ \\
\hline $\mathbf{7}$ & land types & Forest & Hillocks in Tirutanni & $\mathbf{1 9 , 7 3 6}$ \\
\hline
\end{tabular}

(iv) Area, Production and Productivity of major crops cultivated in the district

\begin{tabular}{|c|c|c|c|c|}
\hline S. No & Crop & Area (ha) & $\begin{array}{c}\text { Production } \\
\text { (Tonnes) }\end{array}$ & $\begin{array}{c}\text { Productivity } \\
\text { (kg /ha) }\end{array}$ \\
\hline $\mathbf{1}$ & Paddy & 102657 & 419227 & $\mathbf{4 1 2 1}$ \\
\hline & Millets & & & \\
\hline $\mathbf{2}$ & Cumbu & 710 & 1740 & $\mathbf{2 4 5 0}$ \\
\hline $\mathbf{3}$ & Ragi & 323 & 891 & $\mathbf{2 7 6 0}$ \\
\hline $\mathbf{4}$ & Maize & 14 & 112 & $\mathbf{8 0 0 0}$ \\
\hline & Pulses & & & \\
\hline $\mathbf{5}$ & Redgram & 184 & 166 & $\mathbf{9 0 0}$ \\
\hline $\mathbf{6}$ & Blackgram & 1240 & 868 & $\mathbf{7 0 0}$ \\
\hline $\mathbf{7}$ & Green Gram & 9188 & 8270 & $\mathbf{9 0 0}$ \\
\hline & Oilseeds & & & \\
\hline $\mathbf{8}$ & Groundnut & 7816 & 24230 & $\mathbf{3 1 0 0}$ \\
\hline $\mathbf{9}$ & Gingelly & 914 & 689 & $\mathbf{7 5 4}$ \\
\hline $\mathbf{1 0}$ & Castor & 28 & 8 & $\mathbf{2 7 6}$ \\
\hline
\end{tabular}




\begin{tabular}{|c|c|c|c|c|}
\hline $\mathbf{1 1}$ & Sugarcane & 7211 & 721100 & $\mathbf{1 0 0 0 0 0}$ \\
\hline $\mathbf{1 2}$ & Banana & 2026 & 99486 & $\mathbf{4 9 1 0 4}$ \\
\hline $\mathbf{1 3}$ & Mango & 9944 & 35348 & $\mathbf{3 2 5 0}$ \\
\hline $\mathbf{1 4}$ & Guava & 623 & 6793 & $\mathbf{1 0 9 0 4}$ \\
\hline $\mathbf{1 5}$ & Brinjal & 261 & 2790 & $\mathbf{1 0 6 9 0}$ \\
\hline $\mathbf{1 6}$ & Bhendi & 120 & 903 & $\mathbf{7 5 2 5}$ \\
\hline $\mathbf{1 7}$ & Coconut & 1387 & 6141636 & $\mathbf{4 4 2 8 1}$ \\
\hline $\mathbf{1 8}$ & Cow pea & 116 & 87 & $\mathbf{1 5 0 0}$ \\
\hline $\mathbf{1 9}$ & Horse gram & $\mathbf{1 7}$ & $\mathbf{1 3}$ & $\mathbf{1 7 3 6}$ \\
\hline
\end{tabular}

(v) Weather data

\begin{tabular}{|c|c|c|c|c|}
\hline Month & Rainfall & \multicolumn{2}{|c|}{ Temperature ${ }^{\mathbf{C}} \mathbf{C}$} & \multicolumn{1}{c|}{$\begin{array}{c}\text { Relative } \\
\text { Humidity (\%) }\end{array}$} \\
\cline { 3 - 5 } & Maximum & Minimum & Hom \\
\hline April '17 & 0.0 & 39.0 & 26.1 & $\mathbf{4 . 3}$ \\
\hline May'17 & 2.0 & 39.6 & 27.3 & $\mathbf{2 4 . 7}$ \\
\hline June'17 & 62.0 & 37.1 & 27.5 & $\mathbf{7 0 . 1}$ \\
\hline July'17 & 140.0 & 35.4 & 26.4 & $\mathbf{5 3 . 6}$ \\
\hline August'17 & 225.0 & 33.9 & 25.1 & $\mathbf{6 5 . 4}$ \\
\hline September'17 & 51.8 & 33.3 & 25.3 & $\mathbf{8 3 . 0}$ \\
\hline October'17 & 328.0 & 32.6 & 24.6 & $\mathbf{8 6 . 9}$ \\
\hline November'17 & 269.0 & 30.4 & 21.4 & $\mathbf{8 5 . 7}$ \\
\hline December'17 & 72.0 & 29.2 & 20.7 & $\mathbf{8 3 . 4}$ \\
\hline January'18 & 26.0 & 29.7 & 18.8 & $\mathbf{7 8 . 8}$ \\
\hline February'18 & 0.0 & 31.8 & 19.4 & $\mathbf{7 5 . 7}$ \\
\hline March'18 & $\mathbf{0 . 0}$ & $\mathbf{3 4 . 9}$ & $\mathbf{2 1 . 9}$ & $\mathbf{7 4 . 0}$ \\
\hline
\end{tabular}

(vi) Production and productivity of livestock, Poultry, Fisheries etc. in the district

\begin{tabular}{|c|c|c|c|}
\hline Category & Population & Production/day & Productivity \\
\hline \multicolumn{4}{|c|}{ Cattle } \\
\hline \multicolumn{4}{|l|}{ Crossbred } \\
\hline Indigenous & $2,37,868$ & 97812 & 4lit/day/animal \\
\hline Buffalo & 56,397 & 36,746 & 6.5lit/day/animal \\
\hline \multicolumn{4}{|c|}{ Sheep } \\
\hline \multicolumn{4}{|l|}{ Crossbred } \\
\hline Indigenous & 74780 & -- & -- \\
\hline Goats & 187984 & -- & -- \\
\hline \multicolumn{4}{|l|}{ Pigs } \\
\hline \multicolumn{4}{|l|}{ Crossbred } \\
\hline Indigenous & 2418 & -- & -- \\
\hline Rabbits & 2889 & -- & -- \\
\hline \multicolumn{4}{|c|}{ Poultry } \\
\hline \multicolumn{4}{|l|}{ Hens } \\
\hline Desi & 180866 & -- & -- \\
\hline Improved & 152000 & -- & -- \\
\hline Ducks & -- & -- & -- \\
\hline Turkey and others & -- & -- & -- \\
\hline
\end{tabular}




\begin{tabular}{|c|c|c|c|}
\hline Category & Area & Production & Productivity \\
\hline Fish & & & \\
\hline Marine & $25.73 \mathrm{sq} \cdot \mathrm{km}$ & 2995 & -- \\
\hline Inland & 14841 ha & 4076 & -- \\
\hline Prawn & -- & -- & -- \\
\hline Scampi & -- & -- & -- \\
\hline Shrimp & $\mathbf{1 5 9 . 3 6}$ ha & -- & -- \\
\hline
\end{tabular}

vii) Block details of Tiruvallur district

Blocks / Panchayat Unions (14) \& Village Panchayats (526)

\begin{tabular}{|c|c|}
\hline Sl.No & $\begin{array}{c}\text { Block / } \\
\text { Panchayat Union } \\
\text { Name }\end{array}$ \\
\hline 1. & Ellapuram \\
\hline $\mathbf{2 .}$ & Gummidipoondi \\
\hline $\mathbf{3 .}$ & Kadambathur \\
\hline $\mathbf{4 .}$ & Minjur \\
\hline $\mathbf{5 .}$ & Puzhal \\
\hline $\mathbf{6 .}$ & Poonamallee \\
\hline $\mathbf{7 .}$ & Pallipet \\
\hline $\mathbf{8 .}$ & Poondi \\
\hline $\mathbf{9}$. & R.K. Pet \\
\hline $\mathbf{1 0}$. & Sholavaram \\
\hline $\mathbf{1 1}$. & Tiruvallur \\
\hline $\mathbf{1 2}$. & Thiruvalangadu \\
\hline $\mathbf{1 3}$. & Tiruttani \\
\hline $\mathbf{1 4}$. & Villivakkam \\
\hline
\end{tabular}

Since the area for paddy cultivation was high among the cereal crops in Tiruvallur district the paddy crop was selected and paddy farmers from Minjur, Poondiand Pallipatti blocks of Tiruvallur district were taken for the experiment to assess the TNAU mobile app (Paddy expert system) since they were many paddy farmers found in this block. Thirty farmers were selected randomly for this study, out of which ten farmers were selected randomly for each treatment. Among the large number of available ICT tools the TNAU mobile apps (Expert system) is one of the best visual diagnostic and problem solving tool. Out of the six TNAU mobile apps (5 crop oriented and 1 Animal husbandry oriented) the paddy expert system is popularized among the farmers of Tiruvallur district. Three type of treatments among paddy growing farmers such as Farmers own experience, Farmers using existing extension methods for getting information on paddy (Extension officers and dealers) and Farmers using TNAU mobile apps for getting information on paddy were taken for assessment purpose

\section{Results and Discussion}

For Assessing the Tamil Nadu Agricultural University (TNAU) Mobile Apps among Mobile User Group in Tiruvallur District we 
have decided to do the experiment by splitting into three treatments. The details of the treatment were given in the below table.

The experiment was conducted to observe the factors (Time spend, Knowledge gained, Credibility, dependability and Adoption of technology) among the three treatments and the observations are recorded in the table below.

The average time spend by the farmers who used TNAU mobile app (Paddy expert system) for seeking information on paddy cultivation was quick 7 minutes whereothers farmers spends 30 minutes to 4 hours to fetch information from the Extension officers and dealers. The farmers with own experience spends 1 hour to seek information over paddy cultivation.

The farmers using paddy expert system believes the source as highly credible (75\%) compared to the other farmers who believes the conventional extension methods $(50 \%)$ and the farmers with own experience $(50 \%)$.

In case of mobile app (Paddy expert system) the knowledge gained on new technologies is high while in case of their own experience it is nil and the farmers procure information from the extension officers and dealers seems that the information given by them are not new but repeated one.

Adoption of new recommendations/ technologies is about 70 per cent in case of mobile app utilization and 40 per cent and 30 per cent in case of conventional extensional services and farmers own experience respectively.

The rate of adoption was fast among the farmers who used the mobile app (Paddy expert system) because that application made the technologies easily accessible and also user friendly in nature where in other two cases it is difficult to access the information.

From the table it is indictable that dependability of technology source is high to the farmers following own experience and mobile app but in case of conventional method it is moderate.

It is evident that the (To3) Farmers using TNAU mobile app (Paddy expert system) for getting information on paddy cultivation seems to more efficient that others because by using the mobile application they can easily access through to get the credible information and new innovations about paddy cultivation instantly on their own without the help of others by spending minimum time. The farmers who used the TNAU Mobile app (Paddy expert system) gave feedback that the app was efficient in terms of dissemination of advance technologies in crop production.

Table.1 Details of the Experiment

\begin{tabular}{|l|l|}
\hline S.No. & Treatment \\
\hline To:1 & Farmers own experience \\
\hline To:2 & $\begin{array}{l}\text { Farmers using existing extension methods } \\
\text { for getting information on paddy } \\
\text { (Extn.officers and dealers) }\end{array}$ \\
\hline To:3 & $\begin{array}{l}\text { Farmers using TNAU mobile apps for } \\
\text { getting information on paddy }\end{array}$ \\
\hline
\end{tabular}


Table.2 Assessment of the TNAU mobile apps

\begin{tabular}{|c|c|c|c|c|}
\hline S.No & Observation Factors & To1 & To2 & To3 \\
\hline 1. & $\begin{array}{l}\text { a) Time spent over seeking } \\
\text { information on Paddy cultivation. } \\
\text { b) Average time spent }\end{array}$ & $\begin{array}{l}\text { Nil } \\
1 \mathrm{hr}\end{array}$ & $\begin{array}{l}30 \mathrm{mins}-4 \mathrm{hrs} \\
2 \mathrm{hrs}\end{array}$ & $\begin{array}{l}5 \text { mins }-15 \text { mins } \\
7 \text { mins }\end{array}$ \\
\hline 2. & $\begin{array}{l}\text { Credibility over source of } \\
\text { information gained. }\end{array}$ & $\operatorname{High}(50 \%)$ & $\begin{array}{l}\text { Moderately credible } \\
(50 \%)\end{array}$ & Highly credible (75\%) \\
\hline 3. & New knowledge gained & Nil & (Repeated) Nil & Newly gained (50\%) \\
\hline 4. & $\begin{array}{l}\text { Adoption of new } \\
\text { recommendations/ Technologies }\end{array}$ & $30 \%$ & $40 \%$ & $70 \%$ \\
\hline 5. & Ease of access to technology & $\begin{array}{l}\text { Moderately } \\
\text { accessible }\end{array}$ & Difficult to access & $\begin{array}{l}\text { User friendly easier to } \\
\text { access }\end{array}$ \\
\hline 6. & Dependability of source & $\begin{array}{l}\text { Highly dependable } \\
\text { Informal source } \\
\text { (Neighbors) }\end{array}$ & $\begin{array}{l}\text { Moderately dependable } \\
\text { Formal } \\
\text { source(Extension } \\
\text { officer/dealers) }\end{array}$ & $\begin{array}{l}\text { Highly dependable } \\
\text { Mobile App source } \\
\text { (Paddy expert system) }\end{array}$ \\
\hline
\end{tabular}

In conclusion the ICT can be used to provide farmers with reliable information and services, thereby promoting a more remunerative agriculture development. The study that depicts that the farmers utilizing the mobile app had more efficient paddy cultivation practices. The extension workers can demonstrate and train the mobile users in handling and using different useful mobile apps on expert system created by TNAU or other authentic sources which could increase the efficiency of the cultivation practices, improve the knowledge level and adoption of new technologies by the farmers which would lead to improved livelihood.

\section{References}

Dhaka, B1, and K Chayal. 2010. "Farmers ${ }^{e e}$ Experience with Icts on Transfer of
Technology in Changing Agri-Rural Environment." Indian Research Journal of Extension Education 10 (3):114-118. Raghuprasad, Kp, Sc Devaraja, and Ym Gopala. 2012. "Attitude of Farmers Towards Utilization of Information Communicationtechnology (Ict) Tools in Farm Communication." Research Journal of Agricultural Sciences 3 (5):1035-1037.

Tripathi, Kp. 2011. "A Review on Knowledge-Based Expert System: Concept and Architecture." IJCA Special Issue on Artificial Intelligence Techniques-Novel Approaches \& Practical Applications 4:19-23.

Waterman, Donald A. 2004. "A Guide to Expert Systems." Pearson Education.

\section{How to cite this article:}

Rajasekaran, R., V. Jothika and Panneerselvam, R. 2021. Assessment of Tamil Nadu Agricultural University (TNAU) Mobile Apps among Mobile User Group in Tiruvallur District. Int.J.Curr.Microbiol.App.Sci. 10(02): 311-317. doi: https://doi.org/10.20546/ijcmas.2021.1002.036 